\title{
The impact of ownership structure on bank credit risk: Evidence from Bangladesh
}

\author{
Niluthpaul SARKER ${ }^{*}$, Shamsun NAHAR ${ }^{* *}$
}

\begin{abstract}
This study investigates the impact of ownership structure of Commercial Banks on bank credit risk in an emerging market like Bangladesh. Prais Winten regression model is applied to a sample of 32 commercial banks from the year of 2000 to 2014 with 390 observations. The result reveals that National Commercial Banks, depositors' influence, shareholders' influence, liquidity and profitability are negatively associated with credit risk whereas lag risk has a significant positive impact on credit risk. The effect of banks ownership structure on credit risk divulges a delicate governance of the banking sector. The study conveys a momentous implication of research findings in the national economy. It also found that national commercial banks have the tendency of violating the rules and absorbing heavy risk. It suggests that policy maker should rethink about the government ownership of banks. Therefore the denationalization or reducing government ownership structure is highly recommended.
\end{abstract}

Keywords: Quantitative Methods, Statistical Testing, Panel data, Ownership, Banks.

JEL Code Classification: C12; C23.

UDC: 336.71(549.3)

DOI: https://doi.org/10.17015/ejbe.2017.019.02

\footnotetext{
* School of Management, Huazhong University of Science and Technology, P.R. China.

E-mail: niluthpaul@yahoo.com

${ }^{* *}$ School of Accounting, Zhongnan University of Economics and Law, P.R. China.

E-mail: snahar8079@yahoo.com

Copyright @ , 2017 International Ataturk Alatoo University.
} 


\section{Introduction}

Power politics or majority dominancy is the key driver of decision wining race in the corporate world. The scattered opinion invalidates by the rejection of large group of uniform mandates even though good ideas are ignored and perverted agendas are established. The result is very common and presumed in the ordinary rule of sense that magnifies the intentional absorption of extravagant risk for the sake of profit (Shleifer \& Vishny, 1986) that simultaneously creates financial crises. Agency theory also advocates the prudential effect of ownership structure on bank risk. In fact, national commercial banks (NCBs) are politically connected that influenced in aggressive risk taking behavior, the consequences are the eventual bailed out (Faccio, Masulis \& McConnell, 2006; Demirgüç-Kunt \& Detragiache, 2002).

Empirical evidences demonstrate a heterogeneous outcome from the research due to cultural, political, social, and geographical changes of norms. Some researcher (Lang \& So, 2002; Bonin, Hasan \& Wachtel, 2005; Dong et al., 2014) found that NCBs are inefficient and also a burden of the banking sector. The major reasons behind this statement are bureaucracy and lack of capital market access. Moreover, NCBs are controlled by the government and worked for the implementation of political promises. The findings were similar in Angkinand and Wihlborg, (2010); Berger et al., (2005), Innotta et al., (2007), Innotta et al., (2013). They found that NCBs are highly associated with credit risk. The reverse findings are also common in the prior research (Brown \& Dinç, 2011; Cornett et al. 2010). They revealed that NCBs have lower default risk but higher operational risk compared to private commercial banks (PCBs). The grounds are the stronger government protection and transparent political image in the market place.

The objective of this paper is to identify the relationship between ownership structure and bank credit risk in the developing country context. The ideas-tic approach of the financial market regulation is not controlled entirely by the authoritative body like securities exchange commission (SEC) and central bank of the country. The outcome shows a neglected figure in the control mechanism of the corporate culture as a tonic of financial crises. It also investigates the shareholders' as well as depositors' influence on credit risk. The scenario depicts the reaction of shareholders' and depositors' adoptability in aggressive risk taking behavior of banks. Both the parties are reluctant in risky investment because of their safety and average expectation.

The motivation of this paper is the rational choice of undermine economy in the South Asian region which suffers from the improper guidance of academic research. There are very few research scopes in this area due to social, cultural, political and economical vulnerability of the country. Moreover, many researchers avoid this country as a sample due to limited availability of information in the world wide data base system. This study critically examines the published annual reports of the commercial banks and shows the effect of ownership structure with their 
risk taking behavior. Furthermore, it also investigates the probable relation among the default risk with shareholders' influence, depositors' influence, financial performance and position of banks. This work will add value in the national economy in formulating new rules or scrutinizing existing governance system to retain a stable financial position over time.

The rest of the paper is organized as follows: the banking trends of Bangladesh to understand the market scenario. Next section is literature review and the construction of hypothesis on the impact of several factors based on bank level information. The research design is discussed in the fourth section and the results are presented in the fifth section of the paper. The final section summarizes the whole discussion and also mentions the implications for further research.

\section{Banking trends of Bangladesh}

The present scenario of the banking system of Bangladesh has its long history of socio-economical as well as political transformation. The ownership reform allows privatization in a tiny part of the financial sector in 1982. During the period, two out of six National Commercial Banks (NCBs) were denationalized due to some valid reasons. These were diminishing profitability, growing non-performing assets, capital shortfall, low recovery rate, excessive government interference and lack of supervision (Hassan, 1994; Sayeed, 2002). The severe findings extracted from Bhattacharya and Chowdhury (2003), Raquib (1999) and World Bank report (1998) revealed that accounting and audit qualities are insufficient and internal control system were malfunctioning. These evidences were sufficient to prove the contemporary scenario of banking system in Bangladesh.

However, the private ownership showed its potency and captured a greater number of figures in the banking sector from the year of 2001 to till. The gradual improvement flowed on updated accounting and audit policies, strong internal control and compliances and stable democratic governments. On the other hand, NCBs were unable to get rid from the prior position due to strong adoptability of bureaucracy, nepotism, arrogance and unlawful manner from autocratic government from the year 1975 to 1991. The "black trap squad" trained the government employees like a barking dogs who worked like a doll and nothing else. Still now, the mass people carried the burden of these dam bureaucrats in formulating national policies which are always failed and lose huge public money. That is why; government forcedly induced Public Private Partnership (PPP) in social welfare program. The same phenomenon is also applicable in the banking system to strengthen the public private collaboration in accelerating stability, efficiency and development.

The relative performance of NCBs and PCBs in terms of non-performing loan rate, return on equity and capital adequacy are shown in Figure 1. In all these respects it is shown that PCBs are in better condition from the inception of the study year 
2000 to 2014 . The linkage of the chart below logically proves that greater number of shareholders' influence (CAR) abundantly reduce the credit risk (NPLR) of the bank which ultimately boosting the profitability (ROA) in the successive years.

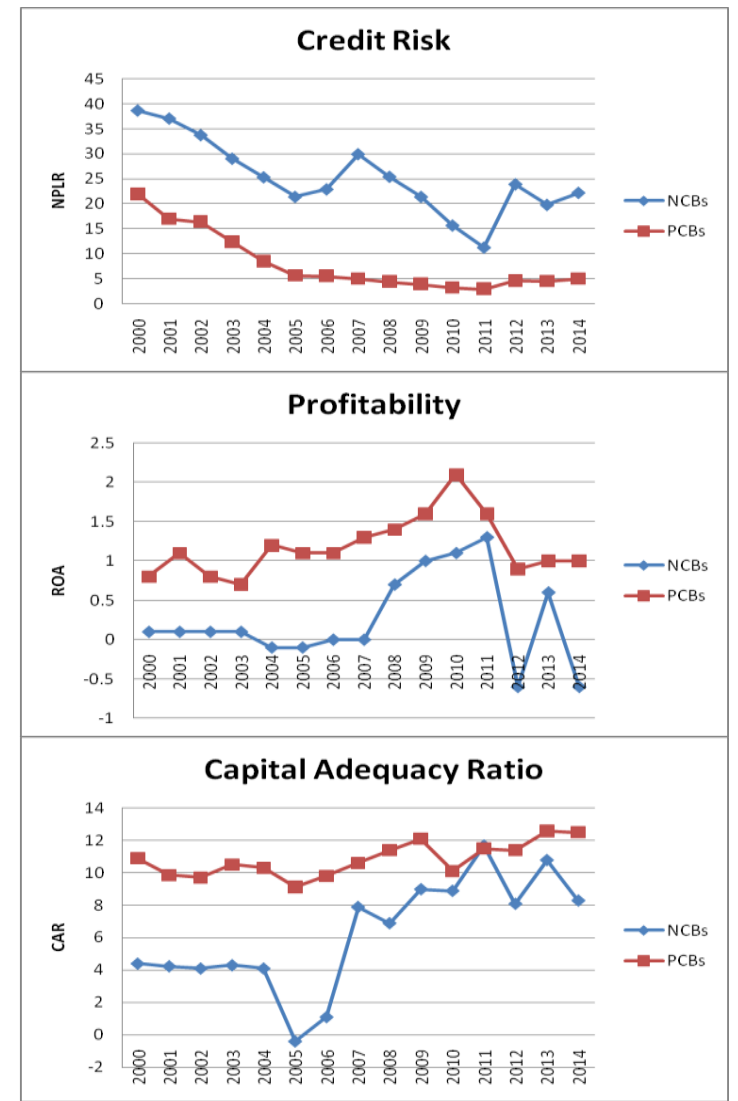

Figure 1. Banking trends of Bangladesh from the year 2000 to 2014

Source: Bangladesh Bank Annual Reports (2000 to 2014)

\section{Literature Review}

Empirical results indicate that ownership structure influences the bank risk in numerous ways. According to lannota et al., (2013), NCBs have lower default risk than PCBs. In the banking crises period of 2007 to 2009, NCBs get rid of this phenomenon due to the capital support by the government. This intervention acts as stimuli for NCBs in its survival and also supports the investors in preventing heavy loss by controlling market vibration. On the contrary, NCBs are controlled by bureaucrats and sometimes conflict with the societal goal (Shleifer \& Vishny, 1986). The reason behind this situation is the establishment of political interests rather than social choices in the norm of hyperbolic intention. 
In conducting existing study, different theories are evaluated and examined to describe the present phenomena in the context of banks ownership structure and credit risk. Several theories are explained the risk responsiveness of banks depending on ownership structure, shareholders' influence and inefficiencies.

Agency theory supports that the risk taking perception is affected by the ownership structure. Shareholders with a diversified portfolio have more incentives and power to influence decisions in order to take more risk whereas managers are risk averse by considering their personal interests in decision making (Shleifer \& Vishny, 1986).

Bad management hypothesis revealed that inefficient banks may face difficulties to evaluate their bad loans and as a result, the cost incurred due to bad management is related with higher default risk (Berger \& DeYoung, 1997). Moral hazard hypothesis also found that there is a positive association between risk and inefficiency and hence the banks are bound to absorb more risk due to increase in inefficiency (Berger \& DeYoung, 1997).

Several studies justified the construction of risk model with significant effect of bank level variables. In our studies, we establish the hypothesis based on prior evidences and also consider economic relevance in regional substances. The variables related with credit risk are stated as follows.

\subsection{Credit Risk}

In this study, we use the accounting measure of bank risk. Accounting based risk can be measured by credit risk, overall risk, default risk, solvency risk, and liquidity risk. The study outlines the extent of response variable as credit risk which is the major representative of bank risk. Credit risk is calculated by the ratio of nonperforming loan to total loan (NPLR), and a higher risk for losses from loan default is associated with higher ratio (Zhang et al., 2013). This ratio is also used by Berger (1995), Shrieves and Dahl (1992) and Gonzalez (2005). Credit risk also termed as counter-party risk, has a significant influence in banking sector (AlTamimi \& Al-Mazrooei, 2007; Richard et al., 2008; Angelini, E., di Tollo, G., \& Roli, 2008; Lin, 2009). This occurs because bank's performance largely depend on credit performance where ineffective credit policy breakdown the sustainability of banks.

\subsection{Ownership Structure}

Ownership structure represents by the dichotomous variable which denotes " 0 " for National commercial bank (NCB) and " 1 " for Private commercial bank (PCB). Theoretically, national commercial banks possess both positive and negative impact on bank risk. Most of the evidences support "Agency theory" in the risk taking behavior of the controlling group. It is assumed that State owned commercial banks in developing countries struggle to strengthen both financial and economical development by implementing social and political agenda and create new opportunities for weaken group of the people which is in vain by private 
financing (La Porta, Lopez-de-Silanes, \& Shleifer, 2002). Behind the light, national commercial banks (NCBs) are mostly inefficient for its bureaucracy and lack of capital market access (Lassoued, Sassi, \& Attia, 2015). Shleifer and Vishny (1986) revealed that national commercial banks face the pressure to implement political promises by granting inefficient projects and also practice excessive power abuse. Lang and So (2002) found that managers of national commercial banks are engaged in personal benefits and misuse of resources. These inefficiency and political arrogances breakdown the supremacy of the rules and regulations and make them the burden of banking sector (Bonin et al., 2005). Several studies (Berger et al., 2005; Angkinand \& Wihlborg, 2010; Cornett, et al., 2010; lannota et al., 2013) concluded their findings by stating that national commercial banks are positively associated with credit risk of the bank. In validating the existing findings, we also verify the result in the developing countries context like Bangladesh and develop the following hypothesis:

$\boldsymbol{H}_{1}$ : There is a significant negative relationship between NCBs and bank credit risk.

\subsection{Depositors' Influence}

Deposits are the major source of finance of the banking organization. However, depositors' can strongly influence the activity of an individual bank based on their deposit decision although it is difficult for small scale of savings. In our study, we calculate the depositors' influence as total deposits divided by total assets which indicate the proportional strength of the deposit-holders in banks decision making role. In fact, bank should consider their current depositors' probable reaction for their future risk taking behavior. Iannotta, Nocera and Sironi (2007) found that depositor's influence is an important determinant of bank risk. However, Soedarmono, Rous and Tarazi (2010) showed a positive relationship between deposit ratio and bank risk in their study. They argued that high deposit ratio indicate high leverage risk which raise moral hazards of banks in investing in risky projects. The study ignored the psychological behavior that depositors can be reluctant in depositing their savings when they feel unsecured. Definitely, they have power to restrain banks from absorbing heavy risk by their prudent decisions. Based on these prior findings, we develop the following hypothesis as:

$\boldsymbol{H}_{2}$ : There is a significant negative relationship between depositors' influence and credit risk.

\subsection{Shareholders' Influence}

Shareholders' influence is expressed by the ratio of total owners' equity to total assets. This is the accounting measure of capital ratio (Lee \& Hsieh, 2013; Tan \& Floros, 2013; Sufian, 2012; Dietrich \& Wanzenried, 2011; Sufian \& Habibullah, 2009; Athanasoglou, Brissimis \& Delis, 2008; Altunbas et al., 2007; lannotta et al., 2007; Amidu \& Hinson, 2006; Kwan \& Eisenbeis, 1996; Shrieves \& Dahl, 1992). It shows the magnifying position of shareholders or proportionate claim on assets. The attitudes of the average owners' are very common which amplify their 
rejection in risky investment. Meanwhile, agency problem can also arise due to increase in capital ratio. In that case, shareholders' influence on bank aggressive credit policy is inversely related because of their average expectation on profits. We can justify our hypothesis like that below:

$\boldsymbol{H}_{3}$ : There is a significant negative relationship between shareholders' influence and credit risk.

\subsection{Liquidity}

Loan to deposit ratio is used to measure the ability of banks to cover withdrawals made by its customers. It also used by the investors and internally by the company to determine its short term viability. Although, profitability theory largely encourage to granting maximum amount of advances with regards to deposits for the sake of higher profit but bank must keep a certain portion of mandatory reserve as guided by the regulators. It also indicates the deposit mobilization of banks that maximize greater return by minimizing lower risk at the best utilization of funds. Portfolio theory says "Don't put all eggs in a single basket" and also promotes higher investment in a diversified way so that probable risk can be consumed by returns. The result is the lower rate of nonperforming loan by increasing higher investment through product diversification. Funso et al. (2012) showed the impact of loan deposit ratio on bank profitability, not on risk. In our study, we developed the hypothesis that:

$\boldsymbol{H}_{4}:$ There is an association between bank liquidity and credit risk.

\subsection{Profitability}

In this study, profitability is measured by the return on asset (ROA) because this is the best representation of the performance measurement scale. Empirical evidence cannot conclude a uniform decision in the effect of profitability on bank risk. Naceur and Omran (2011) found that bank's profitability is positively associated with credit risk although the relation is unexpected but it could happen by imposing overcharge to the customers. However, Guidara et al. (2013) did not find any strong evidence that the change of return on equity has any impact on bank risk. The outcome of every research is limited to the regional diversities that impose the constraints on model specification. That is why, we establish the hypothesis that:

$\boldsymbol{H}_{5}$ : There is a significant association between profitability of bank and credit risk.

\subsection{Inefficiency}

Bank inefficiency is measured by the operating expense to operating income ratio. The reason is that, banks operate their activities to earn profit which is the differential figure between income and expense. To ensure the quality of earnings, banks must rely on core ingredients of income rather than other sources. In this case, efficiency shows ratio by the proper distribution of loan and advances out of 
total deposits. According to "Bad Management" hypothesis, inefficiency is positively associated with the credit risk of the bank. The possible cause for this statement is the increase of nonperforming loan which silently deteriorates the future earnings. Again Kwan and Eisenbeis (1997), Altunbas et al. (2007), and Agusman et al. (2008) found that inefficiency is positively related with risk-taking behavior of banks which is also supported by the "Moral Hazard Hypothesis $(\mathrm{MHH})$ ". These arguments suggest the following hypothesis:

$\boldsymbol{H}_{6}$ : There is a significant negative relationship between inefficiency and bank risk.

\subsection{Bank Size}

Bank size is determined by the logarithm of total assets. Most of the research (Chaibi \& Ftiti, 2015; Tan \& Floros, 2013; Haq \& Heaney, 2012; Fiordelisi, MarquesIbanez \& Molyneux, 2011; Deelchand \& Padgett, 2009; Amidu \& Hinson, 2006; Konishi \& Yasuda, 2004; De Nicolo, 2000; Jacques \& Nigro, 1997;) performed in the bank risk area typically include bank size as a control variable as well as bank level characteristics. This study also tries to find out the effect of bank size on credit risk in the context of Bangladesh. The prior evidence showed a mixed result due to the geographical distinctions. Recent studies conducted by Rahman et al. (2015) in the context of Bangladeshi banks, found that large banks technically hold lower amount of regulatory capital which is sometimes below the thresholds and absorb higher level of risk. Other relevant studies Chaibi and Ftiti (2015); Tan and Floros (2013); Fiordelisi et al. (2011); Amiduand Hinson (2006); Kanishi and Yasuda (2004); Jacques and Nigro (1997) found that bank size is a significant determinant of risk. De Nicolo (2000) exposed in his research that large volume of assets positively behave with the credit risk due to Too-Big-To-Fail (TBTF) safety net subsidies. On the contrary, Haq and Heaney (2012) and Deelchand and Padgett (2009) revealed that bank size has a significant negative impact on credit risk due to better portfolio diversification. Most of the evidences suggest the following hypothesis that:

$\boldsymbol{H}_{7}$ : There is a significant negative relationship between bank size and credit risk.

\section{Methodology}

The study is based on the systematic process to ensure the trustworthiness of the research. To justify the research findings, secondary data are used in empirical quantitative fashion in the study. The main sources of data are the annual reports published by the banks. Annual report is a major source of reliable information among other sources in most of the developing and developed countries because of its availability and wider convenience of information (Akhtaruddin, 2005; Alattar \& Al-Khater, 2007; Catasús, 2008; Chau \& Gray, 2010). Empirical studies (Naser \& Nuseibeh, 2003; Al-Razeen \& Karbhari, 2004) showed that annual report is the formal means of information in the developing countries. But it is not the only means because stakeholder can retrieve information by the direct sources or from other media publications. In this regard, the study is relies on the annual reports as a major source of its data collection. The study also chooses single country 
experiment in its research. The cause is, the socio-political or economic environment of Bangladesh is not in the same track of the Asian region. Moreover, there is a lack of adequate research in the field of credit risk exposure in the financial sector of Bangladesh.

\subsection{Model Specification}

In order to examine the ownership structure effects on bank credit risk taking behavior in banking sector of Bangladesh, we generate the following regression model:

CRISK $_{\text {it }}=\beta_{1}+\beta_{2}$ OWNER $_{\text {it }}+\beta_{3}$ DINFLU $_{\text {it }}+\beta_{4}$ SINFLU $_{\text {it }}+\beta_{5}$ LIQUID $_{\text {it }}+\beta_{6}$ PROFIT $_{\text {it }}+\beta_{7}$ INEFFIC $_{i t}+\beta_{8}$ SIZE $_{i t}+\beta_{8}$ CRISK $_{i t-1}+\varepsilon$

$$
\begin{array}{rlrl}
\text { Where, } & i=1 ; 2 ; 3 \ldots \ldots \ldots \ldots \ldots \ldots ; 32 & & n=32 \text { (banks) } \\
t & =2000 ; \ldots \ldots \ldots \ldots . . . &
\end{array}
$$

The nature of the data set is panel data where include 32 commercial banks and time series of fifteen (15) years. Several studies (Baltagi, 2001; Hsiao, 1986) found that panel data controls individual heteroskedasticity, reduces multicollinearity and biased estimation problem. In our study, we examine the heteroskedasticity (White) test which accepts the null hypothesis at $1 \%$ significance level and also test serial correlation (Breusch-Godfrey serial correlation LM test) which also significant at $1 \%$ level. These diagnoses result restrict in using ordinary least square (OLS) method in the model. The correlated random effect (Hausman test) ensures that there is a random effect on the given data set. Additional analyses are conducted based on further diagnosis to support the outcome of the research.

The data set is restricted due to the problem of heteroskedasticity, cross-sectional correlation and first order auto regressive correlation AR (1) in the error terms. The Prais Winsten Regression (PCSE) methods can overcome the limitation of the existing data set (Wooldridge, 2006). This method allows cross-sectional correlation and heteroskedasticity across panels. In our study, we interpret the results based on PCSE methods and also prove the robustness of the model.

\subsection{Data}

The data set are constructed based on panel data consists of 15 years (2000-2014) time series data and 32 commercial banks longitudinal data. The total number of observation is 390. In 2001, there are 47 banks operated in Bangladesh consists of 4 categories of schedule banks. These are- National commercial banks (NCBs), Development finance institutions (DFIs), Private commercial banks (PCBs) and Foreign commercial banks (FCBs). Structure of the banking sector with breakdown by type of banks is shown in Table 1. The study focuses on both NCBs and PCBs because both capture maximum proportions of industry assets which are $83.70 \%$ in 2001 and $90.80 \%$ in 2014. Moreover, in terms of deposits and the number of branches consideration, NCBs and PCBs have the highest and significant contribution in contrasting with the other banks. For this reason, we select 4 NCBs 
and 28 PCBs (excluded 2 banks for outliers and unavailability of reports) for our experimental group.

Table 1. Comparative scenario by types of bank

\begin{tabular}{lcccccccc}
\hline \multirow{2}{*}{\begin{tabular}{l} 
Bank by $\begin{array}{l}\text { 2001(December) } \\
\text { types }\end{array}$ \\
\cline { 2 - 9 }
\end{tabular}} & $\begin{array}{c}\text { Number Number of } \\
\text { of Banks }\end{array}$ & $\begin{array}{c}\text { \% of } \\
\text { Industry } \\
\text { Assets }\end{array}$ & $\begin{array}{c}\text { \% of } \\
\text { Deposits }\end{array}$ & $\begin{array}{c}\text { Number } \\
\text { of Banks }\end{array}$ & $\begin{array}{c}\text { Number of } \\
\text { Branches }\end{array}$ & $\begin{array}{c}\text { \% of } \\
\text { Industry } \\
\text { Assets }\end{array}$ & $\begin{array}{c}\% \text { of } \\
\text { Deposits }\end{array}$ \\
\hline NCBs & 4 & 3,608 & 46.5 & 50.93 & 5 & 3,553 & 27.5 & 28 \\
DFIs & 5 & 1,298 & 9.5 & 5.64 & 3 & 1,500 & 3.7 & 3.4 \\
PCBs & 30 & 1,331 & 37.2 & 36.58 & 39 & 3,917 & 63.3 & 63.9 \\
FCBs & 12 & 34 & 7.8 & 6.85 & 9 & 70 & 5.5 & 4.7 \\
Total & $\mathbf{5 1}$ & $\mathbf{6 , 2 7 1}$ & $\mathbf{1 0 0}$ & $\mathbf{1 0 0}$ & $\mathbf{5 6}$ & $\mathbf{9 , 0 4 0}$ & $\mathbf{1 0 0}$ & $\mathbf{1 0 0}$ \\
\hline
\end{tabular}

Source: Bangladesh Bank (https://www.bb.org.bd)

\section{Empirical Results}

\subsection{Univariate Analysis}

Descriptive statistics presented in Table $\mathbf{2}$ below is constructed using SPSS 17. The response variable (NPLR) has a very little deviation which is $7.57 \%$ within the year and among the banks. Among the explanatory variables, OWNER has mean value of 91\% which represents the dichotomous variables " 1 " for PCBs and " 0 " for NCBs. In this study, we used four (4) state owned banks where $100 \%$ shares are government owned and twenty eight (28) private commercial banks where 0 existence of government ownership were found. The noticeable figure is the minimum value of SINFLU which is $-12.94 \%$ even though the average value is $7.09 \%$. We found that Rupali bank Ltd in 2007, 2008, 2009 and Sonali Bank Ltd in 2006 have negative owners' equity to total asset ratio. Thus, we can infer that government owned banks are reluctant to recover their loan which increases the credit risk.

Table 2. Descriptive Statistics

\begin{tabular}{lllllllll}
\hline & CRISK (\%) & OWNER & DINFLU (\%) & SINFLU (\%) & LIQUID (\%) & PROFIT (\%) & INEFFIC (\%) & SIZE \\
\hline $\mathrm{N}$ & 390 & 390 & 390 & 390 & 390 & 390 & 390 & 390 \\
Mean & 6.84 & 0.91 & 81.27 & 7.09 & 81.76 & 1.41 & 42.81 & 11.11 \\
St. dev & 7.57 & 0.28 & 5.16 & 2.96 & 11.27 & 1.37 & 12.44 & 0.99 \\
Min & 0.04 & 0 & 62.18 & -12.94 & 8.35 & -13.52 & 17.85 & 8.57 \\
Max & 44.59 & 1 & 93.54 & 15.43 & 107.78 & 6.05 & 90.52 & 13.74 \\
\hline
\end{tabular}

However, government may made promises under political pressure which can increase the default risk. Moreover, it is also remarkable that LIQUIDITY depicts maximum value of $107.78 \%$ which encourage the aggressive banking for both types of banks as they are giving more loans and advances against deposits. Specially, private commercial banks are aggressive to earn more profit as they mobilize their deposits as loans. On the other hand, PROFITABILITY reveals minimum negative value of $-13.52 \%$ as three (3) NCBs have incurred losses for several years. INEFFICIENCY contains maximum value of $90.52 \%$ that indicates a high level of 
inefficiency as well as management failure. This also evidenced that government owned bank (Janata, Rupali, Sonali Bank Ltd.) for the year of 2007 and 2012 consecutively incur more operating expense compared to operating income. The mean value of SIZE represents the Ln value of total assets which is 11.11 with standard deviation of 0.99 .

The Spearman correlation analysis was performed to show the relationship between explained variable (CRISK) and explanatory variables by using SPSS 17 . The results are shown in Table 3. In Table 3, it is found that variables named INEFFICIENCY and SIZE, have a positive correlation with explained variable CRISK $(0.520$ and 0.142$)$ and also statistically significant $(P<0.01)$. It indicates that the high level of credit risk depend on an inefficient operation of commercial banks. Furthermore, variables OWNER, SINFLU, LIQUIDITY and PROFITABILTY have strong negative correlation, which are $-0.544,-0.489,-0.410$, and -0.435 , with CRISK and are statistically significant $(P<0.01)$. Among all the variables, DINFLU has a very low negative correlation with CRISK and statistically significant $(P<0.01)$. The table also shows the relationship among explanatory variables. It shows that the variables are statistically significant but has a low correlation to each other.

Table 3. Spearman Correlation Matrix

\begin{tabular}{|c|c|c|c|c|c|c|c|c|}
\hline & CRISK & OWNER & DINFLU & SINFLU & LIQUID & PROFIT & INEFFIC & SIZE \\
\hline CRISK & 1 & $-.544 * *$ & $-.146 * *$ & $-.489 * *$ & $-.410 * *$ & $-.435^{* *}$ & $.530 * *$ & $.142 * *$ \\
\hline OWNER & & 1 & 0.052 & $.358 * *$ & $.404^{* *}$ & .395 & $-.284 * *$ & $-.446 * *$ \\
\hline DINFLU & & & 1 & $-.379 * *$ & $-.379 * *$ & -0.03 & -0.036 & $-.180 * *$ \\
\hline SINFLU & & & & 1 & $.398^{* *}$ & $.524^{* *}$ & $-.367 * *$ & $.217^{* *}$ \\
\hline LIQUID & & & & & 1 & $.227^{* *}$ & $-.352 * *$ & -0.085 \\
\hline PROFIT & & & & & & 1 & $-.430 * *$ & $-.260 * *$ \\
\hline INEFFIC & & & & & & & 1 & $.178^{* *}$ \\
\hline SIZE & & & & & & & & 1 \\
\hline
\end{tabular}

*.Correlation is significant at the 0.05 level (2-tailed). ${ }^{* *}$.Correlation is significant at the 0.01 level (2-tailed)

\subsection{Multivariate Analysis}

The baseline regression examines the association between explained variable (NPLR) and explanatory variables (CRISK, OWNER, DINFLU, SINFLU, LIQUID, PROFIT INEFFIC and SIZE). The study is conducted on Prais Winsten Regression (PCSE) method to find out the results. The initial test result found that the data set is affected by hetaroskedasticity and serial correlation problem. Moreover, the study shows that the dependent variable has one (1) year lag effect on the model.

From Table 4, we found that the ownership structure (OWNER) is negatively associated with the bank risk (NPLR). Empirical result shows that OWNER is statistically significant at $5 \%$ level. The previous studies (Berger et al., 2005; Angkinand \& Wihlborg, 2010; Cornett et al., 2010 and lannota et al., 2013) also advocate and validate the current result. In Bangladesh, most of the political parties are giving words to the mass people to take mandate in national election. This is the reason that they are trying to implement their political agenda by 
investing more money in social projects (Shleifer \& Vishny 1986). However, PCBs are more responsible to their shareholders' for their actions and do whatever is best for the profit maximization of the firm. The outcome of the study confirms that PCBs are negatively associated with bank credit risk in case of developing country context.

NPLR and DINFLU are statistically significant $(p<.01)$ in the model. The result is similar to lannotta et al., (2007) and contrasting with Soedarmono et al. (2010). In Bangladesh, it is found that, most of the commercial banks especially PCBs are very much concerned about their profit maximization policy. The reason for this practice is the depositors' attitude towards banks' risk taking policy. The study clearly mentions that higher deposit ratio creates substantial pressure to the banks for lowering their credit risk. The result may be occurred by the assumption that after the relevant level, non-performing loan (NPL) becomes constant. As a result higher deposit ratio is the reason of lower the non-performing loan rate (NPLR).

Table 4. Panel data regression of the credit risk (nonperforming loans rate) on the extent of ownershipstructure of the commercial banks in Bangladesh(2000-2014)

\begin{tabular}{|c|c|c|c|c|}
\hline Variables & Coef. & Std. Err. & $T$ & $\mathrm{P}>|\mathrm{t}|$ \\
\hline OWNER & -0.01588 & 0.007857 & -2.02 & $0.044^{*}$ \\
\hline DINFLU & -0.18597 & 0.038692 & -4.81 & $0.000 * *$ \\
\hline SINFLU & -0.19483 & 0.084117 & -2.32 & $0.021 *$ \\
\hline LIQUID & -0.10545 & 0.017087 & -6.17 & $0.000 * *$ \\
\hline PROFIT & -0.00728 & 0.001456 & -5 & $0.000 * *$ \\
\hline INEFFIC & -0.01741 & 0.01516 & -1.15 & 0.251 \\
\hline SIZE & 0.001502 & 0.002074 & 0.72 & 0.469 \\
\hline CRISK $_{\text {it- } 1}$ & 0.628529 & 0.027461 & 22.89 & $0.000 * *$ \\
\hline Constant & 0.289126 & 0.048648 & 5.94 & $0.000 * *$ \\
\hline Observations & 358 & R-squared & $85.22 \%$ & \\
\hline Number of Banks & 32 & Adj. R-squared & $84.88 \%$ & \\
\hline
\end{tabular}

In this model, shareholders' influence (SINFLU) is negatively associated with bank default risk (NPLR) and are statistically significant $(p<.05)$ which is similar to Ho and Hsu, (2010); Agoraki et al., (2011); Lee and Hsieh, (2013); Lee and Chih, (2013). In Bangladesh, it is found that, most of the commercial banks especially PCBs are very much concerned about the regulatory capital requirements and also credit policy. They are aware of granting credits in unproductive sector considering outsiders' pressure. Conversely, shareholders' attitude is negatively associated with bank credit risk (NPLR) policy as they react in the market place through their risk aversion choice. The model also validates the agency theory and also considers the shareholders' behavior towards riskier banks.

The liquidity of banks (LIQUID) shows an inverse relationship with bank credit risk

(NPLR) and also statistically significant at 1\% level. Though there is a little evidence established the relationship between LIQUID and NPLR but Brucker, (1970) 
revealed that the better the financial performance of the bank depends on the higher proportion of resources placed in loans which infers a negative association with default risk (NPLR). The performances of banks are entirely depending on lower credit risk (NPLR) and ensure higher management efficiency.

The profitability (PROFIT) of the banks is negatively associated with bank credit risk and statistically significant at $5 \%$ level. The result contrast with the findings of Naceur and Omran (2011) that return on asset (ROA) has a negative impact on bank credit risk. However, some authors found that profitability is endogenous with credit risk and has a reverse effect. Our findings infers that higher rate of return stimulate banks to take less risk to capture the market. In Bangladesh, it is found that the number of banks increased to 19.15\% from the year 2010 to 2014. Thus, the competition among banks is increasing day by day. The entire scenario beholden the banks to take less credit risk (NPLR) upholding higher profit.

In our model, bank inefficiency (INEFFIC) and bank size (SIZE) are positively associated with bank default risk (NPLR) but statistically insignificant. Prior researches (Chaibi \& Ftiti, 2015; Tan \& Floros, 2013; Fiordelisi et al., 2011; Agusman et al., 2008; Altunbas et al., 2007; Kwan \& Eisenbeis, 1997) showed a mixed result due to the geographical distinctions but our study rejects its statistical significance in the model. In this scenario, the model modified with the statistical relevance and finally arranged as:

CRISK $_{\text {it }}=0.289-0.015$ OWNER $_{\text {it }}-0.185$ DINFLU $_{\text {it }}-0.194$ SINFLU $_{\text {it }}-0.105$ LIQUID $_{\text {it }}{ }^{-}$ 0.007 PROFIT $_{\text {it }}+0.628$ CRISK $_{\text {it- } 1}+\varepsilon$

\subsection{Robustness checks}

The previous analyses allow us to assess the robustness of the model. To check the consistency of the results, we use default risk proxy as loan loss provision to total loan (NPLR). We also conducted the initial diagnosis of Hausman random effect test, White heteroskedasticity test, LM serial correlation test and endogenous test. The result reveals that the data set has a random effect and variables are exogenous but there is problem of heteroskedasticity and auto correlation. In this situation, Wooldridge, (2006) suggested to use PCSE regression model to test the hypothesis. So, we conduct the operation similar to our previous analysis.

Table 5 shows that the bank credit risk (NPLR) is significantly affected by all the dependent variables. In comparing with the baseline model, the deviation of the result is negligible. The result shows that profitability (PROFIT) and inefficiency (INEFFIC) are statistically insignificant $(\mathrm{P}>0.05)$ and size $(\mathrm{SIZE})$ is significant at $1 \%$ level. However, the model explains all the variability of the response data around its mean through its higher percentage of R-squared. In both cases, we can say that the model is best fit because more than $70 \%$ of the data are explained by the independent variables. Moreover, there is no change of coefficient direction in comparing with baseline models. 
Table 5. Panel data regression of the credit risk (loan loss provision rate) on the extent of ownership structure of the commercial banks in Bangladesh (2000-2014)

\begin{tabular}{lllll}
\hline Variables & Coef. & Std. Err. & $\mathrm{T}$ & $\mathrm{P}>|\mathrm{t}|$ \\
\hline OWNER & -0.01776 & 0.005257 & -3.38 & $0.001^{* *}$ \\
DINFLU & -0.15076 & 0.023843 & -6.32 & $0.000^{* *}$ \\
SINFLU & -0.29887 & 0.049734 & -6.01 & $0.000^{* *}$ \\
LIQUID & -0.03902 & 0.010478 & -3.72 & $0.000^{* *}$ \\
PROFIT & -0.00016 & 0.000854 & -0.19 & 0.852 \\
INEFFIC & -0.01562 & 0.009323 & -1.68 & 0.095 \\
SIZE & 0.004243 & 0.001314 & 3.23 & $0.001^{* *}$ \\
CRISK & 0.510568 & 0.036707 & 13.91 & $0.000^{* *}$ \\
CONSTANT & 0.163998 & 0.029691 & 5.52 & $0.000^{* *}$ \\
\hline Observations & 358 & R-squared & $72.35 \%$ \\
Number of Banks & 32 & Adj. R-squared & $71.71 \%$ \\
\hline
\end{tabular}

** Significant at $1 \%$ level, * Significant at $5 \%$ level

\section{Conclusion}

Banking sector plays a vital role in the socio-economic development of the country by ensuring convenient money circulation in the productive uses. As bank works as an intermediary, it is inevitable to distribute the savings as well as timely collection from the debtors. Any mismatch between the lines occur a severe crush in the economy. The study found that government interference in the form of controlling right rigorously affect bank credit risk. The reason behind this occurrence is to whimsical granting of credits by the political pressure and bureaucratic decisions. The growing trends of financial scams and default loan size glimpse a split light on NCBs of Bangladesh. A recent report revealed that NCBs (Sonali bank Ltd.) illegally distributed loans of US\$460 million whereas US\$340 million went to infamous Hallmark group (Mahmood \& Islam, 2015). However, in all respects PCBs maintained an equitable proficiency in loan-deposit trade off and earn a smart amount of profit for the shareholders (Chart 1). The results of the tested hypothesis are given in Table 6 . The issues relating to bank risk should address properly by the regulatory bodies as well as the management of the bank unitedly for ensuring better financial position in the market. Stable financial position attracts the real investors and can avoid market disorder.

\section{Table 6. Summary of hypothesis}

\begin{tabular}{llc}
\hline $\mathbf{N}$ & Hypotheses & Decision \\
\hline $\mathbf{H}_{1}$ & There is a significant negative relationship between NCBs and bank credit risk. & not to reject \\
\hline $\mathbf{H}_{2}$ & $\begin{array}{l}\text { There is a significant negative relationship between depositors' influence and } \\
\text { credit risk. }\end{array}$ & not to reject \\
\hline $\mathbf{H}_{3}$ & $\begin{array}{l}\text { There is a significant negative relationship between shareholders' influence } \\
\text { and credit risk. }\end{array}$ & not to reject \\
\hline $\mathbf{H}_{4}$ & There is a positive association between current and previous years credit risk. & not to reject \\
\hline $\mathbf{H}_{5}$ & There is a significant association between profitability of bank and credit risk. & not to reject \\
\hline
\end{tabular}


The study found a serious concern in the ownership style that government involvement positively affects the risk of the bank which will give evidence to the policy makers about denationalization of existing banks or significantly reduce the government ownership of banks in the succeeding periods.

There is a scope for further extension of the research work in the area of bank risk considering ownership structure as Islamic and Conventional; or Sponsor, Institution and General Public ownership. However, it is also possible to show a regional contrast in the same phenomena.

\section{References}

Agusman, A., Monroe, G. S., Gasbarro, D., \& Zumwalt, J. K. (2008). Accounting and capital market measures of risk: Evidence from Asian banks during 1998-2003. Journal of Banking \& Finance, 32(4), 480-488. https://doi.org/10.1016/j.jbankfin.2006.06.018

Akhtaruddin, M. (2005). Corporate mandatory disclosure practices in Bangladesh. The International Journal of Accounting, 40(4), 399-422. https://doi.org/10.1016/j.intacc.2005.09.007

Alattar, J. M., \& Al-Khater, K. (2008). An empirical investigation of users' views on corporate annual reports in Qatar. International Journal of Commerce and Management, 17(4), 312325. https://doi.org/10.1108/10569210710844381

Al-Razeen, A., \& Karbhari, Y. (2004). Interaction between compulsory and voluntary disclosure in Saudi Arabian corporate annual reports. Managerial Auditing Journal, 19(3), 351-360. https://doi.org/10.1108/02686900410524364

Al-Tamimi Hassan, H. A., \& Mohammed Al-Mazrooei, F. (2007). Banks' risk management: a comparison study of UAE national and foreign banks. The Journal of Risk Finance, 8(4), 394409. https://doi.org/10.1108/15265940710777333

Altunbas, Y., Carbo, S., Gardener, E. P., \& Molyneux, P. (2007). Examining the relationships between capital, risk and efficiency in European banking. European Financial Management, 13(1), 49-70. https://doi.org/10.1111/j.1468-036X.2006.00285.x

Amidu, M., \& Hinson, R. (2006). Credit risk, capital structure and lending decisions of banks in Ghana. Banks and Bank systems, 1(1), 93-101

Angelini, E., di Tollo, G., \& Roli, A. (2008). A neural network approach for credit risk evaluation. The quarterly review of economics and finance, 48(4), 733-755. https://doi.org/10.1016/j.qref.2007.04.001

Angkinand, A., \& Wihlborg, C. (2010). Deposit insurance coverage, ownership, and banks' risk-taking in emerging markets. Journal of International Money and Finance, 29(2), 252-274. https://doi.org/10.1016/j.jimonfin.2009.08.001

Athanasoglou, P. P., Brissimis, S. N., \& Delis, M. D. (2008). Bank-specific, industry-specific and macroeconomic determinants of bank profitability. Journal of International Financial Markets, Institutions and Money, 18(2), 121-136.

https://doi.org/10.1016/j.intfin.2006.07.001

Berger, A. N. (1995). The relationship between capital and earnings in banking. Journal of Money, Credit and Banking, 27(2), 432-456. https://doi.org/10.2307/2077877 
Berger, A. N., \& DeYoung, R. (1997). Problem loans and cost efficiency in commercial banks. Journal of Banking \& Finance, 21(6), 849-870. https://doi.org/10.1016/S03784266(97)00003-4

Berger, A. N., Espinosa-Vega, M. A., Frame, W. S. and Miller, N. H. (2005). Debt Maturity, Risk, and Asymmetric Information. The Journal of Finance, 60: 2895-2923. https://doi.org/10.1111/j.1540-6261.2005.00820.x

Brown, C. O., \& Dinç, I. S. (2011). Too many to fail? Evidence of regulatory forbearance when the banking sector is weak. Review of Financial Studies, 24(4), 1378-1405. https://doi.org/10.1093/rfs/hhp039

Bonin, J. P., Hasan, I., \& Wachtel, P. (2005). Bank performance, efficiency and ownership in transition countries. Journal of banking \& finance, 29(1), 31-53. https://doi.org/10.1016/j.jbankfin.2004.06.015

Catasús, B. (2008). In search of accounting absence. Critical Perspectives on Accounting. 19(7), 1004-1019. https://doi.org/10.1016/j.cpa.2007.02.002

Bhattacharya, D., \& Chowdhury, T. A. (2003). Financial sector reforms in Bangladesh: The next round. CPD Working Paper, No 22, Centre for Policy Dialogue (CPD). Retrieved from http://www.cpd.org.bd/pub_attach/op22.pdf

Chaibi, H., \& Ftiti, Z. (2015). Credit risk determinants: Evidence from a cross-country study. Research in international business and finance, 33, 1-16. https://doi.org/10.1016/j.ribaf.2014.06.001

Chau, G., \& Gray, S. J. (2010). Family ownership, board independence and voluntary disclosure: Evidence from Hong Kong. Journal of International Accounting, Auditing and Taxation, 19(2), 93-109. https://doi.org/10.1016/j.intaccaudtax.2010.07.002

Cornett, M. M., Guo, L., Khaksari, S., \& Tehranian, H. (2010). The impact of state ownership on performance differences in privately-owned versus state-owned banks: An international comparison. Journal of Financial Intermediation, 19(1), 74-94. https://doi.org/10.1016/i.jfi.2008.09.005

Deelchand, T., \& Padgett, C. (2009). The relationship between risk, capital and efficiency: Evidence from Japanese cooperative banks. ICMA Centre Discussion Papers in Finance DP2009-12. https://doi.org/10.2139/ssrn.1525423

Demirgüç-Kunt, A., \& Detragiache, E. (2002). Does deposit insurance increase banking system stability? An empirical investigation. Journal of monetary economics, 49(7), 13731406. https://doi.org/10.1016/S0304-3932(02)00171-X

De Nicolo, G. (2001). Size, charter value and risk in banking: An international perspective. International Finance Discussion Papers, 689. https://doi.org/10.2139/ssrn.255465

Dietrich, A., \& Wanzenried, G. (2011). Determinants of bank profitability before and during the crisis: Evidence from Switzerland. Journal of International Financial Markets, Institutions and Money, 21(3), 307-327. https://doi.org/10.1016/i.intfin.2010.11.002

Dong, Y., Meng, C., Firth, M., \& Hou, W. (2014). Ownership structure and risk-taking: Comparative evidence from private and state-controlled banks in China. International Review of Financial Analysis, 36, 120-130. https://doi.org/10.1016/i.irfa.2014.03.009

Faccio, M., Masulis, R. W., \& McConnell, J. (2006). Political connections and corporate bailouts. The Journal of Finance,61(6), 2597-2635. https://doi.org/10.1111/j.1540$\underline{6261.2006 .01000 . x}$ 
The impact of ownership structure on bank credit risk: Evidence from Bangladesh

Fiordelisi, F., Marques-Ibanez, D., \& Molyneux, P. (2011). Efficiency and risk in European banking. Journal of Banking \& Finance, 35(5), 1315-1326. https://doi.org/10.1016/i.jbankfin.2010.10.005

Funso Kolapo, T., Ayeni, R. K., \& Oke, M. O. (2012). Credit Risk and Commercial Banks'performance In Nigeria: A Panel Model Approach. Australian Journal of Business and Management Research, 2(2), 31

Gonzalez, F. (2005). Bank regulation and risk-taking incentives: An international comparison of bank risk. Journal of Banking \& Finance, 29(5), 1153-1184. https://doi.org/10.1016/j.jbankfin.2004.05.029

Guidara, A., Lai, V., S., Soumaré, I., \& Tchana, F. T. (2013). Banks' capital buffer, risk and performance in the Canadian banking system: Impact of business cycles and regulatory $\begin{array}{llll}\text { changes. Journal of Banking \& } & \text { 3373-3387. }\end{array}$ https://doi.org/10.1016/j.jbankfin.2013.05.012

Haq, M., \& Heaney, R. (2012). Factors determining European bank risk. Journal of International Financial Markets, Institutions and Money, 22(4), 696-718. https://doi.org/10.1016/j.intfin.2012.04.003

Hassan, K. (1994), "The financial sector reform of Bangladesh". Thoughts on Economics, 3(12), 40-64.

lannotta, G., Nocera, G., \& Sironi, A. (2007). Ownership structure, risk and performance in the European banking industry. Journal of Banking \& Finance, 31(7), 2127-2149. https://doi.org/10.1016/j.jbankfin.2006.07.013

lannotta, G., Nocera, G., \& Sironi, A. (2013). The impact of government ownership on bank risk. Journal of Financial Intermediation, 22(2), 152-176 https://doi.org/10.1016/i.jfi.2012.11.002

Jacques, K., \& Nigro, P. (1997). Risk-based capital, portfolio risk, and bank capital: A simultaneous equations approach. Journal of Economics and Business, 49(6), 533-547. https://doi.org/10.1016/S0148-6195(97)00038-6

Kwan, S., \& Eisenbeis, R. A. (1997). Bank risk, capitalization, and operating efficiency. Journal of financial services research, 12(2-3), 117-131. https://doi.org/10.1023/A:1007970618648

Konishi, M., \& Yasuda, Y. (2004). Factors affecting bank risk taking: Evidence from Japan. Journal of Banking \& Finance, 28(1), 215-232. https://doi.org/10.1016/S03784266(02)00405-3

Lang, L \& So, R. (2002). Bank ownership structure and economic performance. Chinese University of Hong Kong, mimeo.

La Porta, R., Lopez-de-Silanes, F., \& Shleifer, A. (2002). Government ownership of banks. The Journal of Finance, 57(1), 265-301. https://doi.org/10.1111/1540-6261.00422

Lassoued, N., Sassi, H., \& Attia, M. B. R. (2016). The impact of state and foreign ownership on banking risk: Evidence from the MENA countries. Research in International Business and Finance, 36, 167-178. https://doi.org/10.1016/i.ribaf.2015.09.014

Lee, C. C., \& Hsieh, M. F. (2013). The impact of bank capital on profitability and risk in Asian banking. Journal of international money and finance, 32, 251-281.

https://doi.org/10.1016/j.jimonfin.2012.04.013

Lin, S. L. (2009). A new two-stage hybrid approach of credit risk in banking industry. Expert Systems with Applications, 36(4), 8333-8341. https://doi.org/10.1016/j.eswa.2008.10.015 
Mahmood, R., \& Islam, M. M. (2015). Practices of Corporate Governance in the Banking Sector of Bangladesh. International Journal of Managing Value and Supply Chains, 6(3), 17 29. https://doi.org/10.5121/ijmvsc.2015.6302

Naceur, S. B., \& Omran, M. (2011). The effects of bank regulations, competition, and financial reforms on banks' performance. Emerging markets review, 12(1), 1-20. http://doi.org/10.1016/i.ememar.2010.08.002

Naser, K., \& Nuseibeh, R. (2003). Users' perceptions of corporate reporting: evidence from Saudi Arabia. The British Accounting Review, 35(2), 129-153. https://doi.org/10.1016/S08908389(03)00015-5

Rahman, M.M., Zheng, C. and Ashraf, B.N. (2015). Bank Size, Risk-taking and Capital Regulation in Bangladesh, Eurasian Journal of Business and Economics, 8 (15), 95-114. https://doi.org/10.17015/ejbe.2015.015.05

Raquib, A. (1999). Financial Sector Reform in Bangladesh: An Evaluation. Bank porikroma, XXIV (3-4), 1-19.

Richard, E., Chijoriga, M., Kaijage, E., Peterson, C. and Bohman, H. (2008). Credit risk management system of a commercial bank in Tanzania. International Journal of Emerging Markets, 3(3), 323-332. https://doi.org/10.1108/17468800810883729

Sayeed, Y. (2002). Bangladesh: Strategic Issues and Potential Response Initiatives in the Finance Sector: Banking Reform and Development. In seminar organized by Asian Development Bank and AIMS of Bangladesh, Dhaka, July 22.

Shleifer, A., \& Vishny, R. W. (1986). Large shareholders and corporate control. Journal of political economy, 94 (3), 461-488. https://doi.org/10.1086/261385

Shrieves, R. E., \& Dahl, D. (1992). The relationship between risk and capital in commercial banks. Journal of Banking \& Finance, 16(2), 439-457. https://doi.org/10.1016/03784266(92)90024-T

Soedarmono, W., Rous, P., \& Tarazi, A. (2010). Bank capital requirement, managerial selfinterest and risk-taking: Evidence from Indonesian banks. LAPE Working Paper. Retrieved from http://www.researchgate.net/publication/228122365

Sufian, F. (2012). Determinants of bank profitability in developing economies: empirical evidence from the South Asian banking sectors. Contemporary South Asia, 20(3), 375-399. https://doi.org/10.1080/09584935.2012.696089

Sufian, F., \& Habibullah, M. S. (2009). Determinants of bank profitability in a developing economy: empirical evidence from Bangladesh. Journal of business economics and management, 10(3), 207-217. https://doi.org/10.3846/1611-1699.2009.10.207-217

Tan, Y., \& Floros, C. (2013). Risk, capital and efficiency in Chinese banking. Journal of International Financial Markets, Institutions and Money, 26, 378-393. https://doi.org/10.1016/j.intfin.2013.07.009

World Bank (1998). Bangladesh: Strategy for establishing a sound and competitive Banking sector, 1 \& 2. Finance and Private Sector Unit, South Asian Region, World Bank. http://documentos.bancomundial.org/curated/es/564931468007258790/pdf/179410ESWO Bang101public10BOX358335B.pdf

Zhang, J., Jiang, C., Qu, B., \& Wang, P. (2013). Market concentration, risk-taking, and bank performance: Evidence from emerging economies. International Review of Financial Analysis, 30, 149-157. https://doi.org/10.1016/i.irfa.2013.07.016. 